\title{
Screening and Molecular Identification of Cellulase-producing Bacillus spp. from Agricultural Soil: its potential in biological control
}

\section{Mohamed M. Gharieb ${ }^{1}$, Gaber A. Abo-Zaid ${ }^{2}$, Shimaa I. Bashir ${ }^{3}$ and Elsayed E. Hafez}

${ }^{I}$ Botany Department, Faculty of Science, Menoufia University, Egypt.

${ }^{2}$ Bioprocess Development Department, Genetic Engineering and Biotechnology Research Institute, City of Scientific Research and Technological Applications, New Borg El-Arab City, 21934, Egypt.

${ }^{3}$ Plant Protection and Biomolecular Diagnosis Department, Arid Lands Cultivation Research Institute, City of Scientific Research and Technological Applications, New Borg El-Arab City, 21934, Egypt.

Received: 15 Mar. 2020 / Accepted 30 April 2020 / Publication date: 10 May 2020

\begin{abstract}
Bacillus spp. were isolated from rhizosphere soils on LB agar plate. Forty cellulolytic bacteria were isolated and screened for production of cellulase enzyme on a basal agar medium containing carboxymethyl cellulose $(0.5 \% \mathrm{w} / \mathrm{v})$ as a sole carbon source. Among them, 23 isolates were identified as good producers of cellulase, which were then quantified. The crud enzyme of the selected isolates was harvested, after $24 \mathrm{~h}$ incubation, and tested for enzyme activity. Isolate B71 had the highest extracellular cellulase activity at $0.05 \mathrm{U} / \mathrm{ml}$. The molecular analysis of 16S rRNA gene showed a close relationship between the isolate B71 and Bacillus subtilis HGUP332. This bacterial isolate showed a high antagonistic activity toward Pythium spinosum where the percentage of inhibition was up to $50 \%$ as compared to control.
\end{abstract}

Keywords: Cellulase, Bacillus subtilis, CMC, phylogenetic tree and biocontrol.

\section{Introduction}

Cellulose is the most common biodegradable, renewable and recyclable biopolymer on the earth. Cellulose is a high molecular weight polymer of glucopyranose units linked together by $\beta-(1,4)$ glycosidic bond and naturally occur in a pure form or accompanied by other biopolymers such as hemicelluloses and lignin (Qiu and $\mathrm{Hu}, 2013$ ). Cellulases are extracellular enzymes which hydrolyze cellulosic compound and produced by various microorganisms during their growth (Immanuel et al. 2009). Recently, cellulase has a great attention due to its potential application in industries such as food processing, pharmaceutical, paper, biofuel production and agriculture (Bhat and Bhat, 1997). Cellulases belong to the glycoside hydrolase family that catalyzes the hydrolysis of glycosidice bonds in large molecule of carbohydrates (Behera and Ray, 2016).

They were categorized depend on their mode of action and the three main categories include (1) endoglucanase (EC 3.2.1.4); which act randomly on the internal $\beta-1,4$ glycoside linkages, (2) Exoglucanase (EC 3.2.1.91); that catalyzes the hydrolysis of $\beta-1,4$ glycosidic bond from either reducing or non-reducing end in the main polymer chain, and (3) $\beta$-Glucosidase (EC 3.2.1.21); that liberate glucose molecules from the non-reducing end of soluble cellobiose and cellodextrins (Sadhu and Maiti, 2013).

The majority of commercial cellulases are produced from fungi because of their ability to produce abundant amounts of the enzyme. However, bacteria have received a great attention to be used in cellulase production because of their high growth rate, wide natural habitat and ability to produce multienzyme complex system (Maki et al. 2009). Cellulase produced by bacteria belongs to different genera such as Bacillus, Cellulomonas, Pseudomonas, Clostridium, Erwinia and Bacteroides (Immanuel et al., 2006). Among them Bacillus spp. are the most promising genus for its capacity to produce a large quantity of extracellular enzymes. Moreover, Bacillus spp. are endospore forming bacteria and produce secondary metabolites; including production of antibiotics, which provides selective advantages in nature (Lynd et al., 2002).

The present study aims to isolate cellulase-producing Bacillus strain from rhizosphere of healthy plants. Study their cellulolytic activity on broth media. Identify and molecular characterize the most

Corresponding Author: Shimaa I. Bashir, Plant Protection and Biomolecular Diagnosis Department, Arid Lands Cultivation Research Institute, City of Scientific Research and Technological Applications, New Borg El-Arab City, 21934, Egypt. E-mail: y_basher@yahoo.com 
promising isolate for the possible use at large scale. Evaluate the antagonistic activity of the selected isolate against a phytopathogen Pythium spinosum.

\section{Materials and Methods}

\section{Isolation and screening of cellulase producing bacteria}

The soil samples were collected from different agricultural sites (Menoufia government, 2017). To isolate Bacillus spp., ten grams of soil were suspended in $90 \mathrm{ml}$ sterile distilled water, and then serially diluted 5 -fold. The resulting dilutions were heat-shocked at $70^{\circ} \mathrm{C}$ for $30 \mathrm{~min}$, and about $100 \mu \mathrm{l}$ of each dilution was spread on LB agar plates and incubate at $37^{\circ} \mathrm{C}$. Bacillus spp. were selected based on morphological character of the colony. Screening of the cellulase producing isolates was carried out by spotting the isolates on $\mathrm{CMC}$ agar plate containing (per liter): $1.0 \mathrm{~g} \mathrm{NaNO}_{3}, 1.0 \mathrm{~g} \mathrm{~K}_{2} \mathrm{HPO}_{4}, 1.0 \mathrm{~g}$ $\mathrm{KCl}, 0.5 \mathrm{~g} \mathrm{MgSO}_{4} .7 \mathrm{H}_{2} \mathrm{O}, 0.5 \mathrm{~g}$ yeast extract, $5.0 \mathrm{~g} \mathrm{CMC}, 20.0 \mathrm{~g}$ Agar and adjust the $\mathrm{pH}$ to 7.0 before autoclaving. After incubation at $37^{\circ} \mathrm{C}$ for 2 days, the plates were stained using $0.1 \%$ congo red stain for $40 \mathrm{~min}$, then the stain was removed by adding $0.5 \mathrm{M} \mathrm{NaCl}$ for $10 \mathrm{~min}$. Cellulytic activity was measured by the clear zone around the colony. Twenty-three isolates were selected based on the diameter of the clear zone $(\geq 15 \mathrm{~mm})$ to further test cellulase activity in liquid media.

\section{Quantitative screening for cellulase production}

The selected isolates were grown in LB broth medium and agitated at $200 \mathrm{rpm}, 37^{\circ} \mathrm{C}$ for $18 \mathrm{~h}$. An aliquot of the bacterial cultures were transferred into $50 \mathrm{ml} \mathrm{CMC}$ broth medium to obtain an initial $\mathrm{OD}=0.25$ at $550 \mathrm{~nm}$, and then incubated at $37^{\circ} \mathrm{C}$ on rotary shaking for $24 \mathrm{~h}$. After growth, the cultures were centrifuged at $10000 \mathrm{rpm}$ for $10 \mathrm{~min}$ at $4^{\circ} \mathrm{C}$ and the cell-free supernatants were used as crude enzyme for estimate cellulase activity using 3, 5-dinitrosalicylic acid (DNSA) method.

\section{Enzyme assay}

Cellulase activity was estimated using 3,5-dinitrosalicylic acid (DNSA) Miller (1959) and Sternberg et al. (1977). An equal volume of $1 \%$ CMC prepared in $50 \mathrm{mM}$ citrate buffer $\mathrm{pH} 4.8$ and crude enzyme were mixed, the mixture was incubated at $60^{\circ} \mathrm{C}$ for $20 \mathrm{~min}$ and the reaction stopped by adding $1 / 4$ volume DNS solution. Samples and substrate blank were boiled for $5 \mathrm{~min}$, cooled in ice-bath and the absorbance was record at $550 \mathrm{~nm}$ against blank. The unit of cellulase activity is the amount of enzyme liberating $1 \mu \mathrm{mol}$ reducing sugar per min.

\section{Molecular identification and phylogenetic analysis}

The isolate exhibiting highest cellulase production were selected for the molecular studies. Genomic DNA isolation was carried out according to Bollet et al. (1991). The 16S rRNA gene was amplified using $16 \mathrm{~S}$ rRNA gene primers. The reaction mixture $(25 \mu \mathrm{l})$ contained $5 \mu \mathrm{l}$ of Taq red buffer, $20 \mathrm{ng}$ of template DNA, $10 \mathrm{pmol}$ of each primers, $0.25 \mathrm{U}$ of Taq polymerase (Bioline, UK). PCR cycling conditions were: $95^{\circ} \mathrm{C}$ for $2 \mathrm{~min}, 30$ cycles of $95^{\circ} \mathrm{C}$ for $1 \mathrm{~min} ; 55^{\circ} \mathrm{C}$ for $1 \mathrm{~min} ; 72^{\circ} \mathrm{C}$ for $1 \mathrm{~min} ; 1$ cycle of $72^{\circ} \mathrm{C}$ for $5 \mathrm{~min}$. The PCR product was purified with GF-1 PCR clean-up kit_and sequencing. The similarity search was carried out using BLAST of NCBI (http://bast.ncbi.nlm.nih.gov/Blast.cgi). Phylogenetic analysis was performed using MEGA-X version 10.0.5 (https://www.megasoftware.net/).

\section{In-vitro study of antagonistic activity of Bacillus sp. against Pythium spinosum}

\section{Isolation of pathogen}

Cucumber seedlings affected by damping-off disease were collected and used for the isolation of a plant pathogen oomycete Pythium spinosum. The pathogen was isolated and purified on potato dextrose agar (PDA) medium at $28^{\circ} \mathrm{C}$. The purified culture was kept at $4{ }^{\circ} \mathrm{C}$ until further use.

\section{Dual culture assay}

The assay was carried out as described by Gohel et al. (2004) with some modification. $P$. spinosum was grown in $250 \mathrm{ml}$ Erlenmeyer flask containing $50 \mathrm{ml}$ of potato dextrose broth for $48 \mathrm{~h}$ at $28^{\circ} \mathrm{C}$ under static condition. After 2 days, the flasks were supplemented with an overnight culture of Bacillus isolate to achieve an initial $\mathrm{OD}_{550}$ of 0.01 and 0.02 and re-incubated to complete 7 days. The $P$. spinosum culture (free from bacteria) was used as control. The growth inhibition of the pathogen was monitored by measuring mycelium dry weight. All treatments were performed in triplicate. 


\section{Statistical analysis}

The obtained data were represented as the mean \pm standard deviation and analyzed by analysis of variance (ANOVA) using the Wasp version 2.0. The Critical Difference (CD) at $P=0.05$ was used to compare the means controls against the rest of the treatments.

\section{Results}

\section{Screening for cellulolytic bacteria}

Forty bacterial isolates were obtained from the collected samples and characterized as Bacillus spp. depends on morphological features including dry and irregular edged colonies with rod-shaped cells. Cellulolytic activities of the bacterial isolates were assayed by spotting on CMC-agar plates, followed by flooding with $0.1 \%$ congo red after incubation. The halo zone around the colonies indicates CMC degradation and cellulase production by them (Table 1 and Figure 1). All bacterial isolates showed different cellulase activity, and only twenty three isolates (with clear zone more than $15 \mathrm{~mm}$ ) were selected to secondary screening.

Table 1: Mean of clear zone values $(\mathrm{mm})$ of cellulase enzyme produced by bacterial isolates isolated from agriculture soil.

\begin{tabular}{|c|c|c|c|}
\hline Isolate & Clear zone $(\mathrm{mm})$ & Isolate & Clear zone (mm) \\
\hline B96 & 24 & B87 & 24 \\
\hline B13 & 19 & B98 & 21 \\
\hline B23 & 09 & B19 & 15 \\
\hline B22 & 16 & B84 & 19 \\
\hline B11 & 16 & B103 & 12 \\
\hline B15 & 12 & B118 & 10 \\
\hline B3 & 15 & B88 & 20 \\
\hline B12 & 10 & B10 & 17 \\
\hline B71 & 23 & B7 & 17 \\
\hline B10 & 12 & B6 & 11 \\
\hline B66 & 15 & B17 & 13 \\
\hline B8 & 08 & B18 & 17 \\
\hline B97 & 11 & B30 & 12 \\
\hline B63 & 22 & B97 & 12 \\
\hline B20 & 16 & B89 & 15 \\
\hline B36 & 15 & B76 & 15 \\
\hline B2 & 15 & B75 & 16 \\
\hline B16 & 20 & B4 & 15 \\
\hline B1 & 10 & B64 & 23 \\
\hline B9 & 20 & B5 & 12 \\
\hline
\end{tabular}

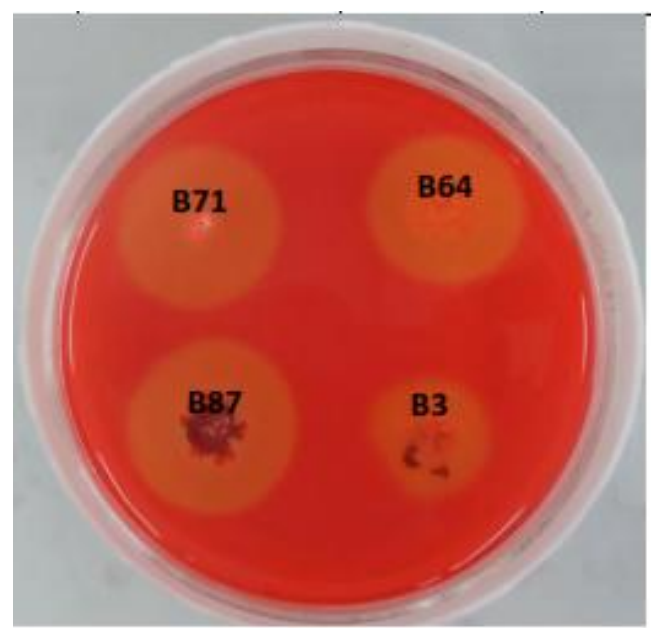

Fig. 1: Clear zone around the bacterial colonies, after staining with $0.1 \%$ congo red and destain with $1 \mathrm{M} \mathrm{NaCl}$, indicates $\mathrm{CMC}$ degradation. 
Cellulase activity was quantified by growing the selected isolates on broth medium containing carboxymethyl cellulose as a sole carbon source. Among the 23 selected isolates, the isolate B71 showed a maximum cellulase activity at $0.05 \mathrm{U} / \mathrm{ml}$ (Figure 2). Eight isolates exhibited moderate enzyme activity range from 0.04 to $0.35 \mathrm{U} / \mathrm{ml}$, while fourteen isolates showed low levels of activity ( 0.022 to $0.007 \mathrm{U} / \mathrm{ml})$

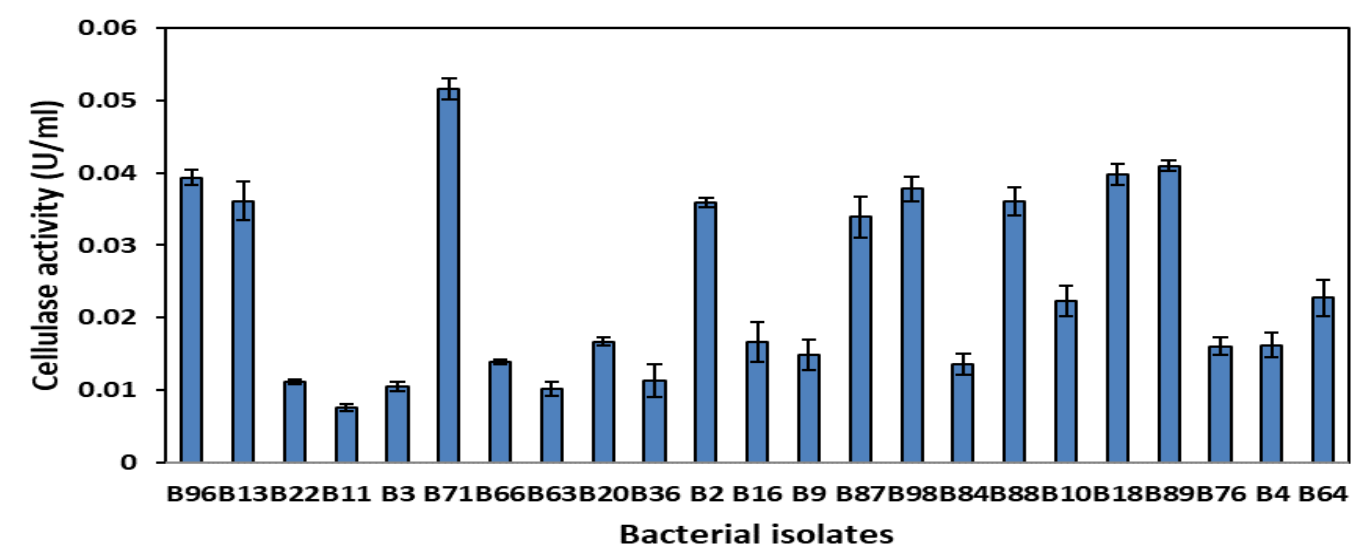

Fig. 2: Cellulase activity $(\mathrm{U} / \mathrm{ml})$ of bacterial isolate after growth at $37^{\circ} \mathrm{C}$ for $24 \mathrm{~h}$. Vertical bar represent standard error.

\section{Sequence analysis of $16 \mathrm{~S}$ rRNA gene}

The genomic DNA of the isolate B71 was used as a template for amplification of 16S rRNA gene. After visualization of the PCR product on $1.5 \%$ agarose gel, a specific DNA band was shown at the length of $1500 \mathrm{bp}$ (Figure 3). The amplified product was subjected to DNA sequencing and the data was compared with the GeneBank database using a BLAST program. The sequence analysis showed that the 16S rRNA sequence had highest homology (>98\%) with Bacillus subtilis. The phylogenetic analysis revealed that this strain was closely related to Bacillus subtilis strain HGUP 332 with a similarity of $81 \%$ (Figure 4 ).

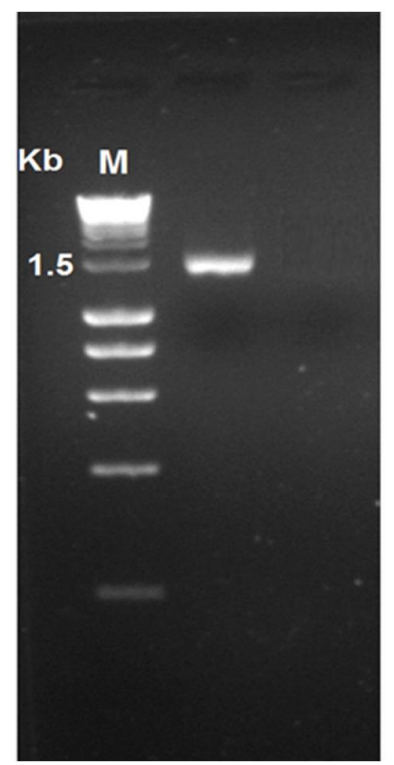

Fig. 3: Electrophoresis of the PCR product of $16 \mathrm{~S}$ rDNA of Bacillus isolate on 1.5\% agarose gel (lane $\mathrm{M}: 10 \mathrm{~Kb}$ DNA Marker). 


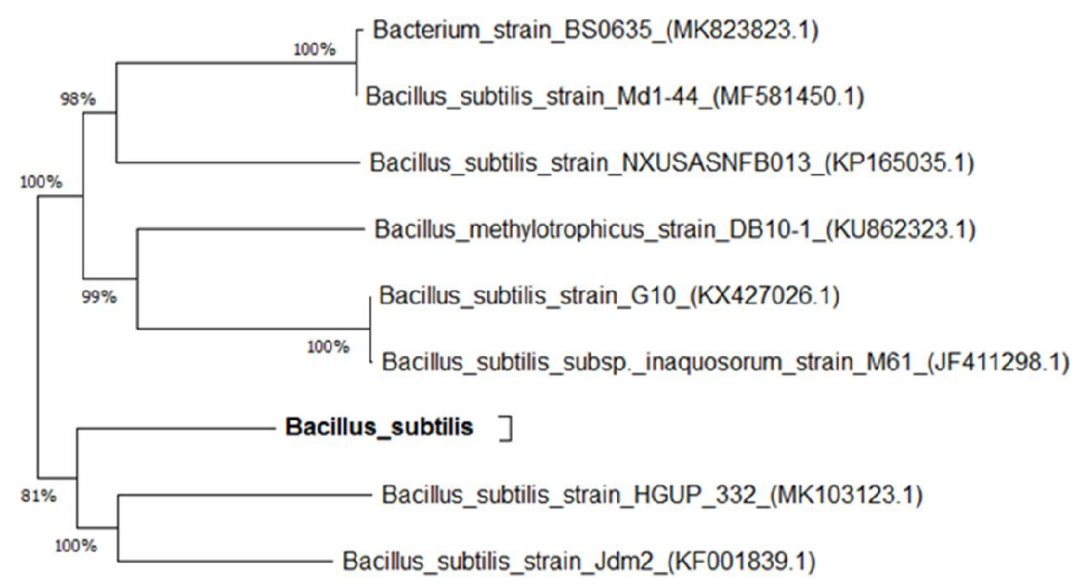

0.50

Fig. 4: Unrooted Phylogenetic tree of Bacillus subtilis spp. isolated from soil.

\section{Antifungal activity of $B$. subtilis by dual cultivation}

In vitro studies were carried out to evaluate the antagonistic activity of Bacillus subtilis against the causal agent of damping-off disease, Pythium spinosum. The obtained results (Table 2) revealed a high efficiency of the bacterial isolate against the phytopathogen. Thus, the growth inhibition of $P$. spinosum reached to $41.12 \pm 1.88$ and $56.14 \pm 5.26$ in the presence of $B$. subtilis at an initial $\mathrm{OD}_{550}$ of 0.01 and 0.02 , respectively, compared with the control.

Table 2: Inhibitory effect of $B$. subtilis on the growth of the plant-pathogenic $P$. spinosium.

\begin{tabular}{ccc}
\hline Bacterial treatment (OD) & Pythium biomass $(\mathbf{g} / \mathbf{l})$ & Inhibition (\%) \\
\hline 0.0 & $7.57 \pm 0.53^{\mathrm{a}}$ & $0.0^{\mathrm{c}}$ \\
0.01 & $4.45 \pm 0.14^{\mathrm{b}}$ & $41.12 \pm 1.88^{\mathrm{b}}$ \\
0.02 & $3.32 \pm 0.39^{\mathrm{c}}$ & $56.14 \pm 5.26^{\mathrm{a}}$ \\
$\mathrm{CD}(P=0.05)$ & 0.783 & 6.45 \\
CV $(\%)$ & 7.66 & 9.96 \\
\hline
\end{tabular}

\section{Discussion}

Agricultural soils are considered as a main source for isolation cellulose degrading microorganisms because of its high content of cellulosic materials. Isolation of cellulolytic bacteria from soils has been reported in several studies. Muhammad et al. (2012) isolated seven different cellulolytic bacteria from the soils and they identified the highly cellulase producing isolate as Cellulomonas sp. ASN2. Patagundi et al. (2014) also reported cellulase activity of Bacillus cereus, Bacillus subtills and Bacillus thuringiensis from garden soil.

Recycling of the cellulosic compound in the environment required participating of microbial enzyme systems. Therefore, cellulose-rich samples such as forest soil (Ashwani et al. 2014), cow dung (Singh et al. 2013) and compost (Marco et al. 2017) are also suitable sources for isolation of cellulaseproducing microorganisms. The isolated Bacillus spp were tested for its efficacy to produce cellulase enzyme using Congo red dye method. Cellulase-producing bacteria utilize CMC as a carbon source and the Congo red dye stained only the unhydrolyzed CMC leaving a clear zone around the colony. Out of 40 isolates, twenty-three isolate showed clear zone range from 15 to $24 \mathrm{~mm}$ after $48 \mathrm{~h}$ incubation. Similar results were observed by Atala et al. (2014) who found the clear zone range between 10 to 14 $\mathrm{mm}$ after incubation for $24 \mathrm{~h}$. Fifteen bacterial isolates showed maximum clearing zone in the range of 25 to $64 \mathrm{~mm}$ during 4-8 days of incubation (Lu et al., 2005). 
Although, plate assay is a simple and fast method; it is not accurate enough because there is no significant correlation-ship between enzyme activity and size of the clear zone (Maki et al. 2009) and the quantitative assay is required. In the present study, the maximum cellulase activity $(0.05 \mathrm{U} / \mathrm{ml})$ showed by the isolate B71 that identified as Bacillus subtilis based on 16S rRNA sequence analysis. This result was very close to other previous studies, for example, Ariffin et al. (2006) found that the maximum CMCase activity $(0.07 \mathrm{U} / \mathrm{ml})$ was produced by Bacillus pumilus EB3. Bacillus subtilis AS3 (Deka et al. 2011), Geobacillus sp. DUSELR7 (Rastogi et al. 2009) and Bacillus amyloliquefaciens SS35 (Singh et al. 2013) reported maximum cellulase activity at 0.07, 0.058 and $0.079 \mathrm{U} / \mathrm{ml}$, respectively. Also, Bhadrecha et al. (2020) isolated seventeen rhizobacteria strains which showed cellulase activity ranged from 0.0070 to $0.0430 \mathrm{U} / \mathrm{ml}$.

Microbes which are able to produce extracellular lytic enzymes have been shown to be more effective to control plant disease. Bacillus spp. are one of the most potential classes of bacteria used for controlling various plant disease (Nagorska et al. 2007). In the present study, B. subtilis isolate was found to strongly inhibit growth of the plant pathogen oomycete, Pythium spinosum. This may be related to the cellulolytic activity of $B$. subtilis. Where, cellulose is a main component of the cell wall of Pythium spp. Similarly, Downer et al. (2001) reported that cellulase enzyme significantly disrupted Phytophthora cinnamomi mycelium and prevent zoospore and chlamydospore formation. Production of cellulase enzyme by Pseudomonas sp. was involved in suppression of plant disease caused by $P$. aphanidermatum (Sindhu and Dadarwal, 2001).

\section{Conflict of interest}

The author (s) they do not have any conflict of interest.

\section{References}

Ariffin, H., N. Abdullah, M.S. UmiKalsom, Y. Shirai, and M.A. Hassan, 2006. Production and characterization of cellulase by Bacillus pumilus EB3. International Journal of Engineering and Technology, 3(1):47-53.

Ashwani, K., L. Saida, and K.V. Reddy, 2014. Isolation, Screening and Characterization of Cellulolytic bacteria from forest soil sample. Int. J. Curr. Microbiol. App. Sci., 3(10):679-685.

Atala, M.L., H.M. Jasim, and K.M. Ibrahim, (2014). Isolation, screening, identification and improvement the production of cellulase produced from Iraqi soil. Int. J. Curr. Microbiol. App. Sci., 3(12): 304-313.

Behera, S.S., and R.C. Ray, (2016). Solid state fermentation for production of microbial cellulases: Recent advances and improvement strategies. International Journal of Biological Macromolecules, 3:656-669.

Bhadrecha, P., M. Bala, Y.P. Khasa, A. Arshi, J. Singh, and M. Kumar, 2020. Hippophae rhamnoides L. rhizobacteria exhibit diversified cellulase and pectinase activities. Physiol Mol Biol Plants. https://doi.org/10.1007/s12298-020-00778-2.

Bhat, M.K. and Bhat, S. (1997). Cellulose degrading enzymes and their potential industrial applications. Biotechnol Adva, 15:583-620.

Deka, D., P. Bhargavi, A. Sharma, D. Goyal, M. Jawed, and A. Goyal, 2011. Enhancement of cellulase activity from a new strain of Bacillus subtilis by medium optimization and analysis with various cellulosic substrates. Enzyme Research, 1-8.

Downer, A.J., J.A. Menge, and E. Pond, 2001. Effects of Cellulytic Enzymes on Phytophthora cinnamomi. Phytopathology, 91:839-846.

Gohel, V., T. Chaudhary, P. Vyas, and H. S. Chhatpar, 2004. Isolation and identification of marine chitinolytic bacteria and their potential in antifungal biocontrol. Indian J Exp Biol., 42(7):71520 .

Immanuel, G., C.M. Bhagwat, I. Raj, P. Esakkiraj, and A. Palavesam, 2009. Production and partial purification of cellulase by Aspergillus niger and A. fumigatus fermented in coir waste and sawdust. The Internet Journal of Microbiology, 3(1): 40-48.

Immanuel, G., R. Dhanusha, P. Prema, and A. Palavesam, 2006. Effect of different growth parameters on endoglucanase enzyme activity by bacteria isolated from coir retting effluents of estuarine environment. Int. J. Environ. Sci. Tech., 3(1): 25-34. 
Kluepfel, D., 1988. Screening of prokaryotes for cellulose-and hemicellulose degrading enzymes. Methods Enzymol, 160:180-186.

Lu, W.J., H.T. Wang, S.J. Yang, Z.C. Wang, and Y.F. Nie, 2005. Isolation and characterisation of mesophilic cellulose degrading bacteria from flower stalks-vegetable waste co-composting system. J. Gen. Appl. Microbiol., 51:353-360.

Lynd, L.R., P.J. Weimer, W.H. van Zyl, and I.S. Pretorius, 2002. Microbial Cellulose Utilization: Fundamentals and Biotechnology. Microbiology and Molecular Biology Reviews, 66(3): 506577.

Maki, M., K.T. Leung and W. Qin, 2009. The prospects of cellulase-producing bacteria for the bioconversion of lignocellulosic biomass. Int. J. Biol. Sci., 5(5): 500-516.

Maki, M., K.T. Leung, and W. Qin, (2009). The prospects of cellulase-producing bacteria for the bioconversion of lignocellulosic biomass. Int. J. Biol. Sci., 5(5): 500-516.

Marco, É.G., K. Heck, , E.T. Martos and S.S.T. van Der, 2017. Purification and characterization of a thermostable alkaline cellulase produced by Bacillus licheniformis 380 isolated from compost. An Acad Bras Cienc., 89(3):2359-2370.

Muhammad, I., A. Safdar, Q. Syed, and N. Muhammad, 2012. Isolation and screening of cellulolytic bacteria from soil and optimization of cellulase production and activity. Turk J Biochem, 37(3):287-293.

Nagorska, K., M. Bikowski, and M. Obuchowski, 2007. Multicellular behavior and production of a wide variety of toxic substances support usage of Bacillus subtilis as a powerful biocontrol agent. Acta Biochim Pol., 54:495-508.

Patagundi, B.I., C.T. Shivasharan, and B.B. Kaliwal, 2014. Isolation and Characterizationof Cellulase producing bacteria from Soil. Int. J. Curr. Microbiol. App. Sci., 3(5): 59-69.

Pearson, W.R. and D.J. Lipman, 1988. Improved tools for biological sequence comparison. Proc. Natl. Acad. Sci. USA, 85(3): 2444-2448.

Qiu, X. and H. Hu, 2013. Smart" Materials Based on Cellulose: A Review of the Preparations, Properties, and Applications. Materials (Basel), 6(3): 738-781.

Rastogi, G., G.L. Muppidi, R.N. Gurram, A. Adhikari, K.M. Bischoff, S.R. Hughes, and R.K. Sani, 2009. Isolation and characterization of cellulose-degrading bacteria from the deep subsurface of the Homestake gold mine, Lead, South Dakota, USA. J Ind Microbiol Biotechnol, 36(4):585598.

Sadhu, S., and T.K. Maiti, 2013. Cellulase Production by Bacteria: A Review. British Microbiology Research Journal., 3(3): 235-258.

Sindhu, S. S., and K. R. Dadarwal, 2001. Chitinolytic and cellulolytic Pseudomonas sp. antagonistic to fungal pathogens enhances nodulation by Mesorhizobium sp. Cicer in chickpea. Microbiological Research, 156(4) : 353-358.

Singh, S., V.S. Moholkar, and A. Goyal, 2013. Isolation, identification, and characterization of a cellulolytic Bacillus amyloliquefaciens strain SS35 from rhinoceros dung. ISRN Microbiology, $1-7$. 